\title{
Seroprevalence of human immunodeficiency virus and various risk factors responsible for spread of human immunodeficiency virus in pregnant women in Jammu, India
}

\author{
Gagandeep Kour $^{1 *}$, Shashi Gupta ${ }^{2}$, Reema Khajuria ${ }^{2}$
}

\begin{abstract}
${ }^{1}$ Department of Obstetrics and Gynaecology, Christian Medical College and Hospital, Ludhiana, Punjab, India ${ }^{2}$ Department of Obstetrics and Gynaecology, Government Medical College and Hospital, Jammu and Kashmir, India
\end{abstract}

Received: 14 August 2016

Accepted: 12 September 2016

\author{
*Correspondence: \\ Dr. Gagandeep Kour, \\ E-mail: drgagan2012@gmail.com
}

Copyright: () the author(s), publisher and licensee Medip Academy. This is an open-access article distributed under the terms of the Creative Commons Attribution Non-Commercial License, which permits unrestricted non-commercial use, distribution, and reproduction in any medium, provided the original work is properly cited.

\begin{abstract}
Background: Human immunodeficiency virus (HIV) is increasing at an alarming rate among pregnant women in various parts of India. Purpose of present study is to investigate the seroprevalence of HIV infection in Jammu region of India and to trace various risk factors responsible for its spread. Another objective is to look for strategies which can be adapted to curtail transmission of this dreadful infection.

Methods: Pregnant women attending the antenatal clinic of Government Medical College and Hospital, Jammu (India) from October 2013 to September 2014, were counseled and those who agreed to undergo testing, were subjected to HIV testing by ELISA method. Pre-designed and post-testing questionnaire was used for collecting the data. In addition, all the unbooked HIV positive patients, who were directly admitted in labor ward and delivered in this hospital during this period, were also included in the present study.

Results: Out of 17918 women attending the antenatal clinic, 5695 agreed for HIV testing at ICTC (integrated counseling and testing center), SMGS hospital and only 5 cases were confirmed positive. Prevalence rate of HIV positivity was found to be $0.088 \%$. Majority of women were between $21-25$ years of age, primigravidas, from rural background, lower middle class and spouses of laborers/drivers.

Conclusions: Seroprevalence of HIV in Jammu region is relatively low when compared to the national figures. More attention is to be focused on the risk factors to control the transmission of HIV infection.
\end{abstract}

Keywords: Seroprevalence, HIV infection, Pregnant women, Risk factors

\section{INTRODUCTION}

Clinically, acquired immuno-deficiency syndrome (AIDS) was first observed in 1981 in United States. ${ }^{1}$ Since then AIDS has become a global pandemic. ${ }^{2}$ In India, first case of AIDS was diagnosed in 1986 among female sex workers in Chennai which was found to be due to contact of some foreign visitors with sex workers. ${ }^{3}$ Thereafter HIV infection spread rapidly from urban to rural areas. After this report, Government of India established AIDS control committee to formulate a strategy for controlling spread of HIV. In the following year, India launched National AIDS Control Programme to cap the problem. ${ }^{4}$ In India, estimated number of people living with HIV is 1.8-2.9 million, out of which $39 \%$ are women with average national prevalence of $0.35 \%$ as assessed from antenatal clinics. ${ }^{5}$ Gender inequality, age at marriage, long distance migration of male workers, variable sexual behavior at various geographical locations, partner's occupation, extramarital and multiple sexual relations, abuse against women, less access to education, lack of employment opportunities forcing many women into commercial sex and other socioeconomic risk factors make the women more susceptible to HIV infection. ${ }^{6}$ Pregnant women are at a higher risk to HIV infection because of decreased immunoglobulin 
complement and a more significant decrease in cellmediated immunity during pregnancy. ${ }^{7}$ Prevalence of HIV among antenatal women is used as a surrogate measure of prevalence in the adult population of the region. Present study was conducted in Jammu (India) to evaluate the seroprevalence of HIV in Jammu region and to identify various risk factors responsible for spread of $\mathrm{HIV}$ in pregnant women in this region.

\section{METHODS}

The study was conducted on all pregnant women attending antenatal clinic and getting tested at ICTC, SMGS hospital, Government Medical College, Jammu from $1^{\text {st }}$ October 2013 to $30^{\text {th }}$ September 2014. All these women were given pre-test counseling regarding HIV infection, its mode of transmission, significance of antenatal testing, the test to be conducted and importance of prophylactic treatment in prevention of mother to child transmission if found positive. Rapid/Immunechromatographic test (ELISA Test) was carried out as per the NACO guidelines. Those found positive, along with HIV positive cases referred from peripheral health centers for delivery were included for studying the risk factors. Partner's testing was also offered to HIV positive women. The results of those found positive were kept strictly confidential. Pre-designed and post-testing questionnaire was used to collect the data. The data was compiled to find out seroprevalence of HIV in pregnant women and various factors contributing to the spread of infection to women.

\section{RESULTS}

Present study was conducted to find the seroprevalence of HIV in antenatal women over a period of one year and to see the distribution of patients with respect to various demographic characteristics. Out of the 17918 women attending antenatal OPD of SMGS Hospital, Government Medical College, Jammu, 5695 underwent HIV testing at ICTC. Of all the women tested, only 5 were found positive for HIV. Thus the seroprevalence of HIV in antenatal women was found to be $0.088 \%$ (Table 1) which is significantly lower than the national prevalence of $0.35 \% 5$. In the study conducted from 2003-2006 in Northern India, the seroprevalence among pregnant women in a tertiary hospital has been found to be $0.88 \%$ which is 10 times higher as compared to the present study. ${ }^{8}$ This shows decreasing trend over past few years due to various AIDS control measures. Seroprevalence varies with country and region. Sub-Saharan region is most severely affected with prevalence as high as $5.04 \%$ in Nigeria. ${ }^{2}$ Our figures show that the problem has not reached an alarming situation in this part of the country. But this is the time to take action for curtailing the spread of this deadly disease and prevention of mother to child transmission (PMTCT).

Majority of the seropositive patients (Table 2) in the present study were in the age group of 21-25 years
(45\%). These findings almost tally with those observed in Northern India and Nagpur where majority of patients (46.94 and $41.94 \%$ respectively) were in the age group of 20-25 years. ${ }^{8,9}$

Table 1: The seroprevalence of HIV in pregnant women.

\begin{tabular}{|c|c|c|c|}
\hline $\begin{array}{l}\text { No. of women } \\
\text { (attending } \\
\text { antenatal) OPD }\end{array}$ & $\begin{array}{l}\text { No. of } \\
\text { antenatal } \\
\text { (women } \\
\text { tested) }\end{array}$ & $\begin{array}{l}\text { No. of } \\
\text { cases }\end{array}$ & Percentage \\
\hline 17918 & 5695 & 5 & $0.088 \%$ \\
\hline
\end{tabular}

Table 2: Distribution of patients according to risk factors.

\begin{tabular}{|c|c|c|}
\hline Parameters variables & $\begin{array}{l}\text { No. of patients } \\
\left(\mathrm{n}=20^{*}\right)\end{array}$ & Percentage \\
\hline \multicolumn{3}{|l|}{ Age (in years) } \\
\hline$\leq 20$ & 2 & $10 \%$ \\
\hline $21-25$ & 9 & $45 \%$ \\
\hline $26-30$ & 8 & $40 \%$ \\
\hline$>30$ & 1 & $5 \%$ \\
\hline \multicolumn{3}{|l|}{ Parity } \\
\hline $\mathrm{P}$ & 10 & $50 \%$ \\
\hline $\mathrm{P}_{1}$ & 3 & $15 \%$ \\
\hline $\mathrm{P}_{2}$ & 6 & $30 \%$ \\
\hline $\mathrm{P}_{3}$ & 1 & $5 \%$ \\
\hline \multicolumn{3}{|l|}{ Residence } \\
\hline Rural & 13 & $65 \%$ \\
\hline Urban & 7 & $35 \%$ \\
\hline \multicolumn{3}{|c|}{ Socioeconomic status (Kuppuswamy's scale) } \\
\hline I & 0 & $0 \%$ \\
\hline II & 1 & $5 \%$ \\
\hline III & 5 & $25 \%$ \\
\hline IV & 14 & $70 \%$ \\
\hline $\mathrm{V}$ & 0 & $0 \%$ \\
\hline \multicolumn{3}{|l|}{ Husband's occupation } \\
\hline Govt. Sector & 1 & $5 \%$ \\
\hline Private Sector & 4 & $20 \%$ \\
\hline Laborer & 8 & $40 \%$ \\
\hline Driver & 7 & $35 \%$ \\
\hline \multicolumn{3}{|l|}{ Husband's HIV status } \\
\hline Positive & 16 & $80 \%$ \\
\hline Negative & 4 & $20 \%$ \\
\hline \multicolumn{3}{|l|}{ High risk behaviour } \\
\hline Positive & 2 & $10 \%$ \\
\hline Negative & 18 & $90 \%$ \\
\hline \multicolumn{3}{|c|}{ Previous blood transfusion } \\
\hline Present & 4 & $20 \%$ \\
\hline Absent & 16 & $80 \%$ \\
\hline
\end{tabular}

*5 cases booked in antenatal clinic and 15 unbooked cases admitted directly in labor room for delivery.

On the other hand a study conducted in South Odisha, India showed higher percentage of cases $(43.8 \%)$ in the 
age group of 25-29 years. $^{10}$ Reason for this age prevalence in our study is the fact that in India most of the women are infected through their husband by heterosexual contact and this is the age when most of the females get married and are sexually active.

\section{DISCUSSION}

In our study, $50 \%$ of the patients were primigravidas. Similar findings were recorded by researchers from Andhra Pardesh and Maharashtra where majority of patients $(53.83 \%$ and $64 \%$ respectively) were primigravidas. $^{11,12}$ Higher percentage of primigravidas may be due to strong belief in our country that delivery process is safe in multigravidas, so they prefer delivery at home to avoid inconvenience in the hospitals.

$65 \%$ of HIV positive women in the present study were from rural and $35 \%$ from urban areas. This is in contrast to the study conducted by some researchers in Kolkata where they found $51.4 \%$ patients belonging to urban areas. ${ }^{13}$ Main reason for higher incidence in present study in rural region is poverty which leads to migration of male members to various parts of the country for earning. These migrants, due to their longer stay away from home may acquire HIV through unsafe sexual contact. During their intermittent return to family they pass on the infection to their spouses which can be probable reason behind higher incidence among rural population.

$70 \%$ of our positive cases belonged to social class IV i.e. upper lower class and $25 \%$ to Class III i.e. lower middle class according to Kuppuswamy's socio-economic scale. ${ }^{14}$ This is in consistence with the observations made on the basis of another study where $80 \%$ of patients were from lower socio-economic class. ${ }^{13}$ This can be attributed to the lower level of education, less access to health care facilities and high rate of promiscuous activities of their husbands making them a vulnerable group. Contrary results were obtained by some investigators who conducted study on pregnant women in Nigeria. ${ }^{15}$ They found that incidence of HIV infection is significantly higher in high income group because affluent attract a lot of social activity which may lead to reckless sexual activities especially among husbands who in turn pass infection to their wives.

In the present study, 95\% of patients were housewives and their husbands were drivers and labourers in $35 \%$ and $30 \%$ cases respectively. Risky sexual behaviour of mobile and traveling population like drivers and labourers have been linked to HIV transmission due to frequent female sex workers contacts, alcohol consumption and presence of various sexually transmitted diseases. The problem can be tackled by public awareness, strengthening of family welfare programmes and sex education especially in rural areas. Educational status of $40 \%$ wives and $40 \%$ husbands in present study was up to matriculation. This is in concurrence with the survey conducted in Belgaum, Karnataka where 35.06\% wives and $38.13 \%$ husbands had education up to matriculation. ${ }^{16}$

Husbands of $80 \%$ women were HIV seropositive in the present study. In a study conducted in Nagpur, Maharashtra, higher seropositivity (96.59\%) was observed in the spouses of such patients. Therefore, routine screening of HIV is advocated for spouses of all women registered in antenatal clinics. ${ }^{9}$

As far as risk behaviour in the present study is concerned, husbands of $10 \%$ of cases had history of multiple sexual contacts. All women admitted that they were monogamous. None of the patients or husbands gave history of I/V drug abuse. Only $20 \%$ of patients had received of blood transfusion in the past. $5 \%$ cases were VDRL positive and 5\% were $\mathrm{HBsAg}$ positive. A study from Kolkata13 found that $45.17 \%$ of husbands and $25.71 \%$ of wives had history of multiple partners, $2.85 \%$ patients had received blood transfusion in the past and $17 \%$ women were commercial sex workers. Low incidence of risk behaviour in our study may be due to non-revelation of multiple sex partners by women and husbands because of social stigma attached to this disease.

All the figures presented above indicate that women are sexually, socially, economically and physiologically more vulnerable to acquire HIV infection. So emphasis is to be laid on integrated approach to induce behaviour changes, promoting use of condoms and control of STDs. These measures may reduce the infectivity of HIV transmitters and susceptibility of HIV exposed persons.

\section{CONCLUSION}

On the basis of observations made in the present study, it is recommended that pregnant women between 20-25 years, particularly primigravidas should be the main focus of agencies connected with HIV control programmes. More attention should be given to rural population, especially lower socio-economic classes. Measures like education, creating awareness about health programmes, behavioral changes, protected sexual intercourse and routine screening of all pregnant women will pave a long way in halting HIV transmission.

\section{ACKNOWLEDGEMENTS}

Authors would like to acknowledge the help provided by Dr. Dinesh Kumar, HOD Community Medicine, ICTC In-charge and Counselor SMGS Hospital, Govt. Medical College, Jammu for their valuable contribution.

Funding: No funding sources Conflict of interest: None declared

Ethical approval: The study was approved by the Institutional Ethics Committee 


\section{REFERENCES}

1. Gottlieb MS, Schroff R, Schanker HM, Weisman JD, Fan PT, Wolf RA et al. Pneumocystis carinii pneumonia and mucosal candidiasis in previously healthy homosexual men: evidence of a new acquired cellular immunodeficiency. N Eng J Med. 1981;305(24):1425-31.

2. Ibekwe PC, Fidelis AO, Joseph A and Paul OE. Human immune deficiency virus (HIV) seroprevalence and pregnancy outcome among obstetric population in Abakaliki, Southeast Nigeria. J Public Health Epidemol. 2012;4(10):290-3.

3. Simoes EAF, Babu PG, John TJ, Nirmala S, Solomon S, Lakshminarayana CS et al. Evidence of HTLV-III infection in prostitutes in Tamil Naidu, India. Indian J Med Res. 1987;85:335-8.

4. Devi AR, Shyamala R. The study of seroprevalence of HIV in pregnant women in a tertiary hospital. Der Pharmacia Lettre. 2012;4(6):1835-6.

5. NACO Annual Report, 2014-15:404. Available at http://www.naco.gov.in/sites/default/files/annual_rep ort\%20_NACO_2014-15_0.pdf. Accessed on 12 January 2016.

6. Farhana A, Saraswathi KS. The study of seroprevalence of HIV in pregnant women in a tertiary care hospital, South India. De Pharmacia Lettre. 2012;4(4):1103-4.

7. Jensin LP, Sullivan MJ, Rao GM, Setzer ES, Gaskin C, Penso C. Acquired immune deficiency syndrome in pregnancy. Am J Obstet Gynaecol. 1984;148(8):1145-6.

8. Gupta S, Gupta R, Singh S. Seroprevalence of HIV in pregnant women in North India: a tertiary care hospital based study. Available at http://www.biomedcentral.com/1471-2334/7/133.

Accessed on 12 August 2013.

9. Pawan MU, Suresh LK, Rajaram MP. Seroprevalence of human immunodeficiency virus infection in pregnancy in a tertiary care hospital. Indian J Med Sci. 2005;59(9):382-7.

10. Dash M, Mohanty I, Sahu S, Narasimham M, Padhi S, Panda P. Declining HIV seroprevalence among pregnant women in South Odisha, India: A six and a half year tertiary care hospital based study. International J Biomed Advance Res. 2012;3(7):54651.

11. Vellanki VS, Gunti SPS, Prasad VG, Koul R. Seroprevalence of HIV in women attending antenatal clinic at KIMS Hospital, Narketpally. Int J Repro Contracept Obstet Gynecol. 2012;1(1):17-22.

12. Giri PA, Bangal VB, Phalke DB. Prevalence of HIV among rural pregnant women attending antenatal clinics at Pravara rural Hospital, Loni, Maharashtra, India. Int J Allied Sci. 2012;1:13-5.

13. Chaudhuri S, Bose S, Talukdar A, Ghosh US. Seroprevalence and utilization of therapeutic intervention in PPTCT services in a teaching hospital in Kolkata. J Obstet Gynaecol India. 2007;57(3):2516.

14. Oberoi SS. Kuppuswamy's socio-economic status scale. a review of income parameter for 2014. Int J Recent Trends Sci Techno. 2014;11(1):01-2.

15. Imade P, Kennedy I, Eghafona N, Enabulele O, Ophon E. HIV seroprevalence among pregnant women attending antenatal clinic in a tertiary health institution in Benin City, Nigeria. Maced J Med Sci. 2010;3(1):43-5.

16. Ashtagi GS, Metgud CS, Walvekar PR, Naik VA. Prevalence of HIV among pregnant women attending PPTCT services at KLE Hospital, Belgaum, India. Al Ameen J Med Sci. 2011;4(1):45-8.

Cite this article as: Kour G, Gupta S, Khajuria R. Seroprevalence of human immunodeficiency virus and various risk factors responsible for spread of human immunodeficiency virus in pregnant women in Jammu, India. Int J Reprod Contracept Obstet Gynecol 2016;5:3552-5. 